4 nordon 



\section{Ekonomiska utsikter i Norden 2010}

Nordiska konjunkturgruppens redogörelse hösten 2009 


\section{Ekonomiska utsikter i Norden 2010}

Nordiska konjunkturgruppens redogörelse hösten 2009

TemaNord 2010:537

(C) Nordiska ministerrådet, Köpenhamn 2010

ISBN 978-92-893-2055-9

Publikationen är tillgänglig som Print on Demand (PoD) och kan beställas på www.norden.org/order. Fler publikationer finns på www.norden.org/publikationer.

Nordiska ministerrådet

Store Strandstræde 18

DK-1255 Köpenhamn K

Telefon (+45) 33960200

Fax (+45) 33960202

www.norden.org

\section{Nordiska rådet}

Store Strandstræde 18

DK-1255 Köpenhamn K

Telefon (+45) 33960400

Fax (+45) 33111870

\section{Det nordiska samarbetet}

Det nordiska samarbetet är ett av världens mest omfattande regionala samarbeten. Det omfattar Danmark, Finland, Island, Norge och Sverige samt de självstyrande områdena Färöarna, Grönland och Åland.

Det nordiska samarbetet är politiskt, ekonomiskt och kulturellt förankrat och är en viktig partner i europeiskt och internationellt samarbete. Den nordiska gemenskapen arbetar för ett starkt Norden i ett starkt Europa.

Det nordiska samarbetet vill styrka nordiska och regionala intressen och värderingar i en global omvärld. Gemensamma värderingar länderna emellan bidrar till att stärka Nordens ställning som en av världens mest innovativa och konkurrenskraftiga regioner. 


\section{Content}

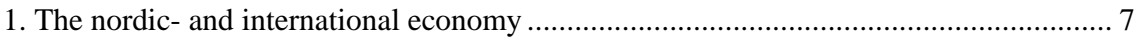

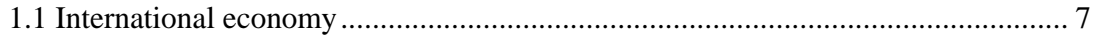

1.2 Economic development in the Nordic countries .................................................. 9

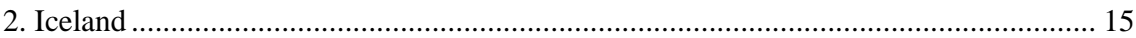

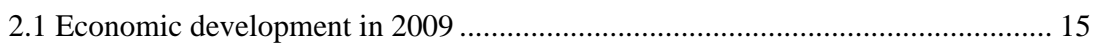

2.2 Economic development in 2010-2011 ........................................................... 19

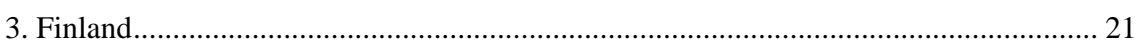

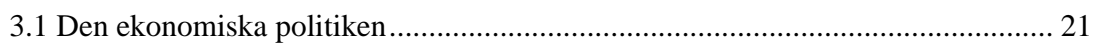

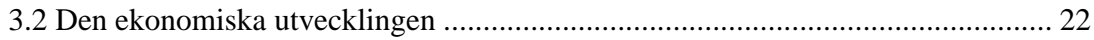

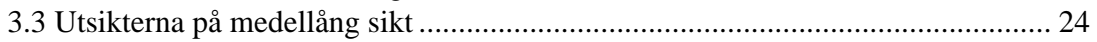

4. Norge

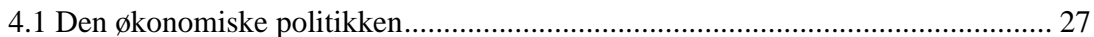

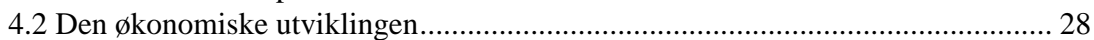

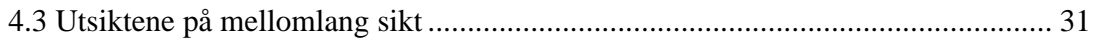

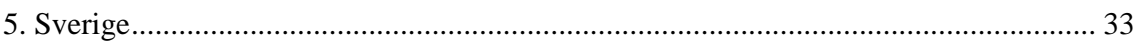

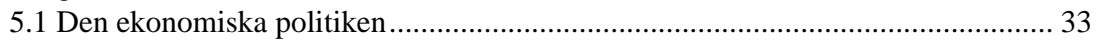

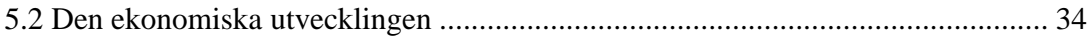

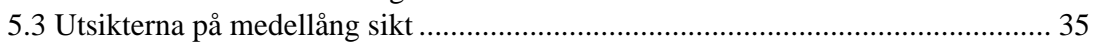

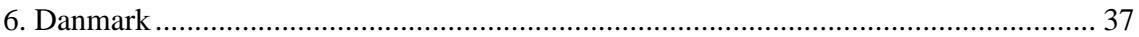

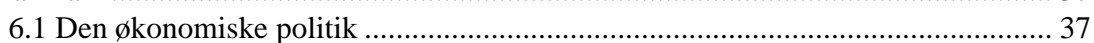

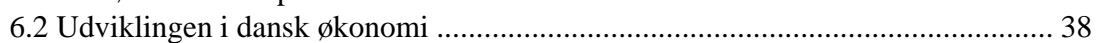

6.3 Udsigterne på mellemlangt sigt .............................................................................. 40 



\section{The nordic- and international economy}

\subsection{International economy}

Prospects for the international economy have improved in recent months, although the immediate future is still fraught with uncertainty. There are already signs that the recession is abating. Financial markets are improving and credit default swap spreads are diminishing to a level more closely in line with normal recession conditions. Stock prices declined last winter and were in March 2009 about half of their October 2007 level. Since spring of this year, stock prices have revived in most areas, although still below their previous highs. There are also signs that international credit markets are limbering up, although credit levels are still lower than in 2008. Economic indicators for the second and third quarter have shown that many developed countries are slowly emerging from the recession, whereas growth in developing countries is accelerating significantly. There are signs in the United States and the euro area that the recession is ending. International institutions estimate that the world economy will have declined in 2009, but predict a slow recovery in 2010. Unemployment is still rising in developed countries and is generally expected to increase for some time before reversing course as economic growth resumes.

The substantial stimulus measure of governments around the world, both through monetary as well as fiscal policies, seem to have resulted in an upturn in asset prices and increased demand. The MCI world share index, has risen by 26 per cent from the beginning of the year, and both financial as well as commodity markets have responded positively. Real property prices in the US have begun increasing, following large declines in recent years. Still, consumers are expected to continue their caution, reducing debt and redressing asset balances. CDS spreads in the US and Europe is currently down to levels prevailing before the October collapse in 2008.

Surveys in US, Europe and Japan show that fewer banks are reducing their loans compared to the situation before the end of last year, although the growth in credit is still declining in major economies. Inventories appear also to be turning around in major economies. At the same time, the sharp contraction in world trade, in the wake of the crisis, is fading out slowly but is still on a sharp downward trend year-on-year and well below its peak of April 2008. Inflation expectations have been within a satisfactory range, and the price increases in recent months in commodity 
markets have helped allay deflation fears. Economic growth began reviving in several developed countries in the second quarter, and the downturn appears to be slower in others, whereas growth is exceeding expectations in emerging market economies such as China.

The economic situation in the United States has improved in some respects since spring, although the downturn for this year as a whole is quite severe, and unemployment is already larger than it has been for nearly three decades. Government measures have already yielded significant results, especially in financial markets. The policy interest rate of the Fed has been reduced to near-zero, liquidity has been injected into the banking system and public funds have been appropriated to increase share capital in systemically important financial enterprises in order to redress their balance sheets. A systemic collapse has been averted for now, and financial markets appear relatively stable, although the situation is still precarious. There are indications that the housing market is reaching its trough. The growth in unemployment has been slowing down, although the unemployment rate reached 10.2 per cent in October, 0.4 percentage points higher than in the previous month and the highest rate since April 1983. Prospects are that unemployment will remain elevated, even as economic growth resumes. International institutions assume that the contraction will end in the latter half of this year, followed by slow growth in 2010 due to excess output capacity. The IMF forecasts a 2.7 per cent contraction in US GDP in 2009, followed by 1.5 per cent growth in 2010 and OECD forecast 2.5 per cent contraction in GDP in 2009 and 2.5 per cent growth next year and 2.8 per cent growth in 2011 .

Europe is going through a major contraction this year but recent data suggest that the pace of the decline is moderating. In the third quarter GDP (euro area) increased by 0.4 per cent as France, Germany and Spain were posting positive growth and UK registering a more moderate decline. Stability in euro area financial market has largely been restored, but the situation is still fragile, and financial enterprises are in the process of restructuring their balance sheets, thus limiting credit growth. The accumulation of inventories is probably turning around, after having dragged down economic growth in recent quarters. Their decline could help economic growth in the near future as export prospects improve. Unemployment has increased in the euro area, although the increase is spread unevenly, with the largest unemployment increases in Spain and Ireland.

The IMF predicts that output in the euro area will decline by 4.2 per cent this year and that the improvement in 2010 will lag behind that of the US, with output increasing by 0.3 per cent in 2010 on average. By the fourth quarter of 2009, a decline of 2.5 per cent is forecast. The OECD forecast 4 per cent contraction in euro-area GDP this year 0.9 per cent growth in 2010 and 1.7 per cent growth in 2011.

Amongst large advanced industrial countries, dimmest prospects appear to be in Japan. The sharp downturn in world trade in the fourth quar- 
ter of 2008 and the first quarter of 2009 hit export-oriented Japan badly. In the first quarter of this year, Japan's GDP declined by 12.4 per cent at an annual rate. As growth in Asia turns up and prospects for world trade improve, along with major stimulus measures of the government, economic growth could probably revive next year. For this year, the IMF forecasts a 5.4 per cent decline in GDP in Japan, followed by 1.7 per cent growth in 2010. The OECD forecast 5.3 per cent decline in GDP this year and 1.8 per cent growth next year and 2 per cent growth in 2011.

Economic growth is increasing in the emerging market economies of Asia, following a slowdown in growth around the turn of last year in concert with the contraction in the occidental world. China and India lead the growth league, as they have done much to stimulate their economies, particularly China. The IMF predicts that Asian EMEs will grow by 5 per cent this year, with growth accelerating to 6.8 per cent in 2010 .

Prospects for the world economy have in many respects improved since the beginning of the year. Both the OECD and the IMF have upgraded their forecasts this autumn for 2009 and 2010. The OECD states that uncertainty surrounding its forecasts is more evenly balanced than earlier in the year, when uncertainties were seen to be on the downside. The greatest uncertainty had to do with financial markets and how they are going to come out of their difficulties that began in 2008. Furthermore, there is uncertainty regarding public debt, especially in the US, where it could force interest rates to rise or cause a slide in the dollar exchange rate. Such developments could have an adverse impact on growth in the world economy.

\subsection{Economic development in the Nordic countries}

\subsubsection{Downward trend in Real GDP growth}

The Nordic countries are experiencing severe economic downturn in the wake of the international financial crisis as most of the developed world. The situation is nowhere as dim as in Iceland which has been hit extremely hard by the crisis and is now going through its worst recession since the establishment of the republic. Real GDP is expected to contract by 7.9 per cent in 2009 due to a major contraction in private consumption and real disposable income. In 2010 GDP is forecast to decline by 2.3 per cent, somewhat more than was forecast this past spring. In accordance with the economic plan worked out with the IMF, it is evident that a tighter fiscal policy is needed to reach budgetary targets for 2010. The exchange rate is now forecast to be weaker than last spring and inflation higher, in turn leading to a more adverse development of Treasury finances. In addition, the net foreign debt of the Treasury is now expected to be higher than before, leading to higher interest rate cost. 
Iceland is however not alone in going through a rough period at the moment. Export-dependent countries such as Sweden and Finland are also facing strong head-winds as global demand has hit rock-bottom. In Sweden 2009 will be the weakest year since the Second World War and the recovery is forecast to be slow. Real GDP is expected to be growing again in 2010 with the help of increased global demand and an expansive fiscal and monetary policy. The recovery in Sweden will, however, be slow as the low capacity utilization in the rest of the world will hamper Swedish exports, which largely consist of investment- and intermediate goods.

In Finland it will also take some time for recovery to take hold due to the export structure. Even though the fall in output has now slowed, the GDP is forecast to contract by 6 per cent this year and record only marginal growth in 2010. Import demand from Finland's traditional trade partners has been sluggish. In the first half of 2009 the value of goods exports fell by one-third compared to corresponding period last year. Exports will decline by 22 per cent in volume in 2009 and export prices will fall considerably. In 2010, it is projected that the exports will rise slightly at around 2 per cent.

In Denmark a drop in demand is projected to lead to a substantial fall in GDP in 2009. Unlike many other countries, a sharp contraction in private consumption has contributed significantly to lower demand. The reduction in production was large in the first half of the year but output expanded in the $3^{\text {rd }}$ quarter and is expected to grow further in 2010, due to the substantial easing of fiscal policy, the sharp drop in interest rates, the ending of inventories adjustments and a gradual recovery in the global economy. In 2010 GDP is forecast to grow at a moderate pace as exports pick up and the expected increase in private consumption in the last part of 2009 is set to sustain and expand in 2010. Together with a historical high growth in public investment, these are the expected driving forces behind the increase in demand and in GDP growth in Denmark in 2010. In 2011, activity is expected to become more self-sustained as economic policy at this point is set to be tightened as temporary measures are withdrawn, while exports and private investments is pulling up demand.

Table 1.1 GDP growth

\begin{tabular}{lrrrrrrrr}
\hline & & & & & \multicolumn{4}{c}{ Forecast } \\
\cline { 6 - 9 } & $\mathbf{2 0 0 4}$ & $\mathbf{2 0 0 5}$ & $\mathbf{2 0 0 6}$ & $\mathbf{2 0 0 7}$ & $\mathbf{2 0 0 8}$ & $\mathbf{2 0 0 9}$ & $\mathbf{2 0 1 0}$ & $\mathbf{2 0 1 1}$ \\
\hline Denmark & 2.3 & 2.5 & 3.4 & 1.7 & -0.9 & -4.3 & 1.3 & 1.6 \\
Finland & 3.7 & 2.8 & 4.9 & 4.5 & 1.0 & -6.0 & 0.3 & $\ldots$ \\
Sweden & 4.1 & 3.3 & 4.1 & 2.7 & -0.2 & -5.2 & 0.6 & 3.1 \\
Iceland & 7.7 & 7.5 & 4.3 & 5.6 & 1.3 & -7.9 & -2.3 & 2.3 \\
Norway (mainland) & 4.4 & 4.6 & 4.9 & 5.6 & 2.2 & -1.1 & 2.1 & $\ldots$ \\
\hline
\end{tabular}

In Norway the downturn seems to be less severe than in the other Nordic countries as the GDP in Mainland Norway is only forecast to decline by 1.1 per cent in 2009. The implementation of extensive liquidity and credit 
policy actions, as well as expansionary fiscal and monetary policy measures, has stabilized the economy and provided stimulus to domestic demand. Monetary policy was quickly eased in the wake of the crisis and from October 2008 to June 2009 the key policy rate was lowered by a total of 4.5 percentage points, to 1.25 per cent. The interest rate is currently 1.50 per cent, after being increased by 0.25 percentage points in late October as activity in the Norwegian economy has picked up more rapidly than expected. Measured by the change in the structural deficit as a share of trend GDP the fiscal stimulus in 2009 can be estimated at 2.7 percentage points. This is the strongest fiscal stimulus recorded in the last 30 years, and fiscal policy in Norway is very expansionary compared to the policies of most of our trading partners. In 2010 real GDP growth forecast for Mainland Norway is 2.1 per cent in the National Budget from October.

\subsubsection{Unemployment is rising fast}

Unemployment rates in the Nordic countries are increasingly reaching high levels. In Iceland, which is not familiar with high unemployment rate figures, unemployment began increasing at a rapid rate in October 2008. Registered unemployment rose faster and reached higher levels than ever before. Registered unemployment rose to 9.1 per cent of the labour force in April when almost 17000 were registered unemployed. It should be noted that a part of this group is part-time unemployed. The number of unemployed has since then declined slightly since employment generally increases over the summer months as unemployment among students turned out to be lower than had been feared. In October registered unemployment had declined to 7.6 per cent. Unemployment is considerably higher among men than women and higher in the capital area than outside it. This reflects the fact that the contraction has hit hardest in the construction sector and private consumption branches. It is by far the highest among the youngest age groups and declines with age.

In Sweden the effects of the economic downturn are becoming increasingly visible in the labour market. The number of people employed has already declined by 100000 since mid-2008 and most labour market indicators point to a continued sharp fall in employment. Unemployment is rising to levels Sweden has not experienced since the crisis of the 1990s and in 2011 unemployment is forecast to reach 11.6 per cent of the labour force. As in the other Nordic countries high unemployment risks leading to permanently lower employment and, as a result, exclusion from the labour market and to counteract such a development is one of the most critical challenges Government's will face in the near future.

In 2009 jobs in Finland will be lost mainly as a result of declining exports, but increasingly because of dwindling domestic demand. The employment rate will fall to under 68 per cent this year, as the number of people in employment will decline by more than 90 000, and the unem- 
ployment rate will rise to an average of 9 per cent. In 2010 the demand for labour will continue to decline with the employment rate falling to around 66 per cent, the same level recorded ten years ago, and the unemployment rate will climb to an average of 10.5 per cent. More and more people who are unemployed will remain out of work for longer periods, which means that structural unemployment will begin to increase as well.

In Denmark employment is expected to fall by around $2 \frac{1}{2}$ per cent in both 2009 and 2010 due mainly to the fall in output that has already taken place and high productivity growth. In 2010 employment will be at approximately the same level as in the beginning of 2006. Unemployment has risen from an extra-ordinary low level. It is forecast to rise further until the end of 2010, but at a lower pace than in the first part of 2009. At this point unemployment is close to the estimated structural level and sligthly below the through, which was reached following the upswing in the 1990'ies.

In Norway employment has declined in 2009 and unemployment has risen, but the Norwegian labour market has performed better than expected. The unemployment was 3.1 per cent of the labour force in the third quarter of 2009. This level of unemployment is about 1 percentage point lower than the average for the preceding 20 years. An unemployment rate of 3.2 per cent is forecast for 2009 and 3.7 per cent for 2010.

Table 1.2 Unemployment, \% of labour force

\begin{tabular}{lrrrrrrrr}
\hline & & & & \multicolumn{5}{c}{ Forecast } \\
\cline { 6 - 9 } & $\mathbf{2 0 0 4}$ & $\mathbf{2 0 0 5}$ & $\mathbf{2 0 0 6}$ & $\mathbf{2 0 0 7}$ & $\mathbf{2 0 0 8}$ & $\mathbf{2 0 0 9}$ & $\mathbf{2 0 1 0}$ & $\mathbf{2 0 1 1}$ \\
\hline Denmark & 5.6 & 4.9 & 3.8 & 2.7 & 1.8 & 3.4 & 5.3 & 5.3 \\
Finland & 8.8 & 8.4 & 7.7 & 6.9 & 6.4 & 9.0 & 10.5 & $\ldots$ \\
Sweden & 7.7 & 7.7 & 7.1 & 6.1 & 6.2 & 8.8 & 11.4 & 11.6 \\
Iceland & 3.1 & 2.1 & 1.3 & 1.0 & 1.6 & 7.9 & 9.6 & 8.6 \\
Norway & 4.5 & 4.6 & 3.4 & 2.5 & 2.6 & 3.2 & 3.7 & $\ldots$ \\
\hline
\end{tabular}

\subsubsection{Public finances}

The economic downturn has put the public finances in most of the Nordic countries into a precarious position. In Iceland the impact from the crisis have been profound both due to lower revenue and rising exenditure, not least through the one-time direct cost from the recapitalization of the Central Bank and the banking sector. The general government finances had been run with a considerable surplus for several years but in 2008 a large deficit emerged. In 2009 it is forecast that the deficit on the general government balance will be 18 per cent of GDP but increased fiscal control measures will be taken in 2010 and 2011 to reduce the deficit according to the economic plan drawn up by the government and the IMF. It is expected that the balance will be in surplus by 2013 .

In Sweden the general government balance will be in deficit from 2009 to 2012 after 2.5 per cent of GDP surplus in 2008. The deficit is almost entirely attributable to the central government and is primarily due 
to the weak development of tax revenues and the increased expenditure on labour market related expenditures. Since last autumn there has been considerable uncertainty about the development of public finances. Indicators and outcomes now point to a stabilization and some improvement in macroeconomic developments, which also affects public finances and both the revenue and the expenditure sides are improving.

In Finland the general government balance has been in surplus since 1998 but in 2009 it will swing sharply into deficit and it will continue to deepen in 2010, or by 7 percentage points relative to GDP. This is a steeper drop than at the height of the previous recessions in 1991, and at the same time the highest estimate, along with Latvia's, for the current year in the EU. Despite slight improvement in the cyclical outlook for 2010 the general government budgetary position will deteriorate further and the deficit to GDP ratio will breach the Stability and Growt'h Pact 3 per cent limit for the first time since Finland joined the EMU.

In Denmark the general government balance is estimated to decline from a surplus of around 31/2 per cent of GDP in 2008 to a deficit of 51/2 per cent of GDP in 2010. Besides substantial fiscal easing the considerable shift reflects that public finances in Denmark are highly sensitive towards cyclical conditions through higher transfer expenditures as the unemployment rises and lower revenues from taxes and duties as employment and demand decrease. The automatic stabilisers account for about two-thirds of the reduction in the general government balance, whereas one-third of the reduction is due to discretionary fiscal policy measures including tax cuts on labour income, a significant increase in public investment, and consumption expenditures in 2009 and 2010. Some improvement of the fiscal balance is expexted in 2011 as activity gathers momentum and the fiscal easing is gradually withdrawn.

In Norway the general government balance is estimated to decline from 18.6 per cent of GDP in 2008 to 7.4 per cent in 2009 and 6.5 per cent in 2010. Lower oil and gas revenues due to lower oil prices and an increase in the non-oil budget deficit are the main reasons for this development. Whilst the non-oil deficit was 0.7 per cent of Mainland Norway GDP in 2008, it is estimated to increase to 6.5 per cent in 2009 and 8.1 per cent in 2010. Roughly half of this weakening is due to fiscal meaures to dampen the cyclical downturn, while the other half can be attributed to automatic stabilisers.

Table 1.3 General government balance, \% of GDP

\begin{tabular}{lrrrrrrr}
\hline & $\mathbf{2 0 0 5}$ & $\mathbf{2 0 0 6}$ & $\mathbf{2 0 0 7}$ & $\mathbf{2 0 0 8}$ & $\mathbf{2 0 0 9}$ & $\mathbf{2 0 1 0}$ & $\mathbf{2 0 1 1}$ \\
\hline Denmark & 5.0 & 5.0 & 4.8 & 3.4 & -3.0 & -5.5 & -4.4 \\
Finland & 2.6 & 3.9 & 5.2 & 4.4 & -2.7 & -4.5 & $\ldots$ \\
Sweden & & & & 2.5 & -2.2 & -3.4 & -2.1 \\
Iceland & 4.9 & 6.3 & 5.4 & -13.6 & -18.0 & -11.5 & -5.1 \\
Norway & 15.1 & 18.5 & 17.8 & 18.7 & 7.4 & 6.5 & $\ldots$ \\
\hline
\end{tabular}





\section{Iceland}

\subsection{Economic development in 2009}

The contraction in the Icelandic economy since the autumn of 2008 is the sharpest in the 65 years since the establishment of the republic. Private consumption has declined by one-fifth after a major contraction in real disposable income. Many businesses have gone bankrupt or contracted sharply and unemployment has soared. Investment has declined by fifty per cent. The exchange rate has been weak in spite of a trade surplus, and the policy interest rate remains at a relatively high level despite the weak state of the economy. Foreign exchange restrictions on capital movements are still in place, and there is considerable uncertainty as to when they can be lifted, since foreign investors still have large holdings in Icelandic securities and hold sizeable domestic deposits. Many businesses and households have debt in foreign currencies, the krónur value of which has increased in line with the fall in the exchange rate. Although banks have attempted to help debtors to adjust their repayment burden, the number of debt defaults has been on the increase. The dispute between Iceland and the UK and the Netherlands, on deposit insurance in relation with Landsbanki deposits, is expected to be resolved in 2010 . This dispute has delayed the disbursement of credits from the IMF and other potential lenders, in turn delaying the recovery measures for the economy. The restoration of the banking system has also been delayed but is close to being completed. The financing of Íslandsbanki is completed as foreign creditors have accepted to take over a 95 per cent share of the bank but it is still needs The Financial Supervisory Authority ordinance. Foreign creditors have also accepted to take over the Arion Bank (the new Kaupping Bank) and according to the agreement the foreign creditors of the failed bank will acquire 87 per cent of the new bank. Through foreign ownership, both Íslandsbanki and Arion Bank will again be linked to the international financial system, since many of the foreign creditors are well-established international financial institutions. An agreement between the Government and the Landsbanki Resolution Committee is expected to be finalized in November. As the composition of creditors of the bank is substantially different from the other two banks, Landsbanki will most likely continue under majority government ownership. Savings banks were badly hit by the fall of the three commercial banks. The government has offered to inject equity into savings banks that fulfill certain criteria. The final outcome of this exercise, which is expected to conclude before year-end, depends i.a. on negotiations between the two largest savings banks and their creditors. 
The current real exchange rate is close to its historic lows. This has led to an adjustment of the economy to shifting circumstances with increased activity in export sectors and increased demand for domestic products and services at the expense of imports. This has in turn yielded a sizeable surplus on the trade account and a considerable improvement in the service account. Increased revenue from tourism has been important in producing a services surplus in the second quarter, following persistent deficits in recent years.

The newly established research department of Statistics Iceland has revised the national economic forecast in view of the finalization of the fiscal budget for 2010. Real GDP is now expected to contract by 7.9 per cent this year even though the year-to-date decline in private consumption has been less than assumed in the Ministry of Finance spring forecast, as real disposable income has not shrunk as much as had been expected. This has partly been caused by the payout of supplementary pension savings and the temporary freeze on credit repayments. However, business investment has dropped more than expected since the construction of the Helguvík aluminium smelter, along with associated power generation investments, has been slower than was forecast last spring. The largest drop in investment has been in residential construction, because the property market has suffered heavily, following its extraordinary expansion in recent years. The rising cost of building has by far exceeded housing prices, which have been falling of late. On the whole, domestic demand is forecast to decline by about one-fifth, leading to a decline in imports of a third and producing a sizeable trade surplus for the year. The world price of aluminium has increased in excess of expectations in the course of the year as well as the value of exports from the aluminium sector. Prices for fish products in foreign currency have been stagnant in recent months. The export value of the fisheries sector is currently high in krónur terms due to the fall in the exchange rate.

Yet, there is great uncertainty ahead for the fisheries sector, since the catch of capelin in the last fishing seasons was poor and the summerspawning herring turned out to be widely infected with a parasite, making it unfit for human consumption. Other exports have increased less than was forecast last spring. It appears that the low exchange rate has not benefited other exports as much as expected. Exports of services have done well, since foreign travellers have taken advantage of the low exchange rate, benefiting tourism shops and the travel industry as a whole. In addition, imports of services have declined sharply since Icelanders travel abroad much less frequently than before. The 2009 current account is expected to be in deficit due to the very high net interest payments to abroad. The development of the factor income account is subject to much uncertainty for this year due to the still unresolved settlements resulting from the bank collapse. 
Table 2.1 Overview of national accounts and Ministry of Finance forecast

\begin{tabular}{|c|c|c|c|c|c|c|c|}
\hline & \multicolumn{7}{|c|}{ Volume change on previous year, $\%$} \\
\hline & \multirow[b]{2}{*}{2005} & \multirow[b]{2}{*}{2006} & \multirow[b]{2}{*}{2007} & \multirow{2}{*}{$\begin{array}{l}\text { Pre. } \\
2008\end{array}$} & \multicolumn{3}{|c|}{ Forecast } \\
\hline & & & & & 2009 & 2010 & 2011 \\
\hline Private consumption & 12.7 & 3.6 & 5.6 & -7.8 & -16.6 & -4.3 & 2.2 \\
\hline Public consumption & 3.5 & 4.0 & 4.1 & 4.6 & -1.1 & -3.6 & -2.0 \\
\hline Gross fixed capital formation & 35.7 & 21.6 & -12.2 & -20.4 & -45.7 & 4.8 & 17.4 \\
\hline National expenditure & 15.8 & 8.4 & 0.1 & -8.6 & -19.3 & -3.0 & 3.5 \\
\hline Exports of goods and services & 7.5 & -4.6 & 17.7 & 7.1 & 1.1 & 1.7 & 2.0 \\
\hline Imports of goods and services & 29.3 & 10.4 & -0.7 & -18.3 & -26.4 & -2.3 & 5.1 \\
\hline Gross domestic production & 7.5 & 4.3 & 5.6 & 1.3 & -7.9 & -2.3 & 2.3 \\
\hline Current account balance (\% of GDP) & -16.2 & -26.0 & -20.7 & -42.2 & -6.6 & -2.0 & -4.1 \\
\hline
\end{tabular}

Sources: Statistics Iceland and Ministry of Finance forecast

Unemployment is now forecast to average 7.9 per cent for this year, more than 1 percentage point less than forecast last spring. Although unemployment was lower than expected last summer, it is expected to increase this winter. Real disposable income is forecast to decline by 9.4 per cent between years. Wage pressures are scant and the rise in the wage index is at a low. Inflation is expected to abate in the course of this year due to a sharp decline in demand and a considerable drop in real property prices. The decline in inflation has so far been less than had been expected, largely because of the drop in the exchange rate in the spring months. In spite of declining inflation, the policy interest rate is not expected to decline much since the exchange rate is still quite weak and is expected to continue that way for the remainder of the year. The negative output gap is forecast to amount to 6.6 per cent of GDP, following several years of a positive gap. The output gap is expected to remain negative throughout the forecast period.

In this analysis, it is assumed that the economic recovery plan agreed to between the Icelandic authorities and the IMF will be carried out, and the goals regarding Treasury finances will be attained. Since the last assessment, it has emerged that the economy's external debt is higher than previously thought and higher inflation than expected last spring it calls for greater fiscal restraint. The Treasury deficit is expected to amount 17.2 per cent of GDP in 2009. The primary deficit - where interest income and payments are excluded - is estimated to amount to 120.4 billion, equivalent to 8.2 per cent of 2009 GDP. The intention is to move the Treasury deficit into surplus by 2013 in line with the economic plan set up in conjunction with the IMF in November 2008. In the 2010 fiscal budget, it is envisaged that an increase in taxes and a reduction in expenditure will improve Treasury finances by 63 billion for the year. The primary deficit is budgeted to be equivalent to 1.5 per cent of GDP in 2010 and turn into surplus of 3.2 per cent of GDP in 2011, 6.4 per cent in 2012 and 8.4 per cent in 2013. Although the primary balance is expected to be in surplus by 2011, the actual revenue balance is expected to continue in deficit due to heavy interest payments. The revenue balance is scheduled 
to be in equilibrium by 2012 and record a surplus in 2013. In order to achieve these goals, cuts will have to be made on the expenditure side and revenue must be increased in the next several years.

Table 2.2 Treasury Finances

\begin{tabular}{lrrrrr}
\hline & & \multicolumn{3}{c}{ Forecast } \\
\cline { 5 - 6 } \% of GDP & $\mathbf{2 0 0 7}$ & $\mathbf{2 0 0 8}$ & $\mathbf{2 0 0 9}$ & $\mathbf{2 0 1 0}$ & $\mathbf{2 0 1 1}$ \\
\hline Total revenue & 34,9 & 32,3 & 28,2 & 30,7 & 32,5 \\
Total expenditure & 31,0 & 45,3 & 45,4 & 40,3 & 36,6 \\
Revenue surplus & 3,9 & $-13,0$ & $-17,2$ & $-9,6$ & $-4,1$ \\
Primary balance & 4,3 & $-12,9$ & $-8,2$ & $-1,4$ & 3,2 \\
\hline
\end{tabular}

Sources: Ministry of Finance

As can be seen in table 2.3, the Treasury balance sheet has changed radically. Treasury debt, which averaged just over 23 per cent of GDP in 2006 and 2007, is estimated to reach 111 per cent of GDP in 2010. This figure does not include credits from the IMF and Norway, since they will be extended to the Central Bank and are not included in this figure. Nor is the guarantee behind Icesave accounts included in Treasury debt. Accumulated but unpaid interest on Icesave accounts is included in Treasury interest payments and is added to Treasury debt each year until the debt has been resolved. The increase in Treasury debt is both in domestic and foreign currency, the majority on the domestic side. Net Treasury debt, i.e. total debt less claims from loans extended and net short-term accounts, amounted to 4 per cent of GDP in 2006 and 2007 but is currently estimated at 60 per cent of GDP in 2010. If assets in the form of company shares, equity capital stakes and asset shares are included along with other financial claims of the Treasury, the net Treasury position was in surplus by 18 per cent of GDP in 2007 but is currently estimated to be in deficit by close to 20 per cent of GDP by 2010 .

Since these figures were estimated and published in the Ministry of Finance Economic Outlook, 1th October, the Glitnir's Resolution Committee has, on behalf of its creditors, decided to exercise the option provided for in its agreement with the Icelandic state and take over 95 per cent share capital in Íslandsbanki. This will reduce the Treasury debt as the government's contribution of refinancing the bank will be lower. If foreign creditors of old Kaupping Bank also decide to exercise the agreement they have with the Icelandic state the Treasury burden of refinancing the new banks will be even lower. This could have positive effects on the economic recovery plan and moderate the neccessary fiscal restraint measures in 2010. 
Table 2.3 Central government debts and assets

\begin{tabular}{lrrrrrr}
\hline & & & \multicolumn{3}{c}{ Forecast } \\
\cline { 5 - 6 } Per cent of GDP & $\mathbf{2 0 0 6}$ & $\mathbf{2 0 0 7}$ & $\mathbf{2 0 0 8}$ & $\mathbf{2 0 0 9}$ & $\mathbf{2 0 1 0}$ \\
\hline Gross domestic debts & 9.8 & 11.7 & 38.3 & 69.1 & 69.4 \\
ross foreign debts & 14.1 & 11.7 & 16.5 & 26.0 & 41.6 \\
Gross total debts & 23.9 & 23.4 & 54.9 & 95.1 & 111.1 \\
Assets & 36.5 & 41.5 & 56.9 & 82.8 & 91.5 \\
Net debt & 3.9 & 4.4 & 22.8 & 58.6 & 59.8 \\
Net financial position & 3.8 & 3.4 & -11.3 & -46.4 & -51.8 \\
Net financial position based on broad financial assets & 12.6 & 18.2 & 2.1 & -12.3 & -19.6 \\
\hline
\end{tabular}

Source: Ministry of Finance

\subsection{Economic development in 2010-2011}

Real GDP is forecast to decline by 1.9 per cent in 2010, somewhat more than was forecast this past spring. In accordance with the economic plan worked out with the IMF, it is evident that a tighter fiscal policy is needed to reach budgetary targets for 2010. The exchange rate is now forecast to be weaker than last spring and inflation higher, in turn leading to a more adverse development of Treasury finances. In addition, the net foreign debt of the Treasury is now expected to be higher than before, leading to higher interest rate cost. Private consumption is forecast to continue declining for the third year in succession, due to a substantial drop in real disposable income, in part due to higher taxes and cuts in public spending. Unemployment is forecast to peak in the course of the year but that it will begin declining in the latter part of the year. The upcoming resolution of the Icesave dispute and the prospective foreign ownership of the new banks may increase access to foreign borrowing, in turn stepping up the pace of power-based investments currently in their initial phase. Tighter public finances will, on the other hand, lead to reduced public consumption and investment both in 2010 and 2011. Housing prices are expected to decline for the second year in a row and housing investment is forecast to change little from the previous year's low level. Housing investment is forecast to be about unchanged throughout the forecast period, since the housing market appears quite saturated at the moment, especially in the capital area.

Foreign trade, on the other hand, is improving and the account of trade and services is expected to be in sizeable surplus throughout the forecast period. The low exchange rate benefits the export sector and aluminium prices are expected to rise. The fish catch and foreign fish prices are, as usual, subject to fluctuations, but the low exchange rate benefits export incomes whereas the operating conditions of the export sector have suffered considerably from the exchange rate drop because most of its debt is in foreign currency. Various other export branches will gradually benefit from the exchange rate, especially when economic growth revives in Iceland's main trading countries and demand increases. The exchange rate has 
already helped tourism, where foreign travellers have taken advantage of the favourable domestic price level. Foreign tourism may be expected to increase, creating increasing income in tourism services as world economic growth rises. General imports will continue to decline next year and in 2011 in line with the contraction in consumption, whereas imports of investment goods will be dictated by increased power-based investment activity. The considerable deficit on factor income account, because of high interest payments to abroad, is going to offset much of the surplus on trade and services on the current account balance.

In 2011, the economy is gradually expected to start pulling out of its slump, with real GDP rising by 2.8 per cent. Private consumption is believed to have bottomed out and is forecast to increase by 2.3 per cent over the year, whereas general investment is forecast to revive at the same time as power-based investment will play an increasing role. Economic policy will continue to be tight in accordance with the government's plan agreed with the IMF and will tend to hold economic growth in check, in part through the continued contraction in public consumption and public investment. The current account is expected to show marginal surplus by then.

Table 2.4 Key economic indicators in Iceland

\begin{tabular}{|c|c|c|c|c|c|c|}
\hline \multirow[b]{2}{*}{ Economic aggregates } & & \multirow[b]{2}{*}{2007} & \multicolumn{2}{|l|}{ Pre, } & \multicolumn{2}{|l|}{ orecast } \\
\hline & & & 2008 & 2009 & 2010 & 2011 \\
\hline Economic growth & $\%$ & 5,6 & 1,3 & $-7,9$ & $-2,3$ & 2,3 \\
\hline National expenditure & Annual growth,\% & $-0,4$ & $-8,6$ & $-19,3$ & $-3,0$ & 3,5 \\
\hline Balance of trade & $\%$ of GDP & $-10,7$ & $-3,2$ & 6,6 & 9,8 & 8,5 \\
\hline Current account balance & $\%$ of GDP & $-20,7$ & $-42,2$ & $-6,6$ & $-2,0$ & $-4,1$ \\
\hline \multicolumn{7}{|l|}{ Labour market } \\
\hline Unemployment & $\%$ of labour force & 1,0 & 1,6 & 7,9 & 9,6 & 8,6 \\
\hline Real hourly wage & Annual change, $\%$ & 3,8 & $-3,6$ & $-7,4$ & $-3,0$ & 0,9 \\
\hline Real disposable income per capita & Annual change, $\%$ & 3,7 & $-7,7$ & $-9,4$ & $-6,4$ & $-0,1$ \\
\hline \multicolumn{7}{|l|}{ Foreign trade } \\
\hline Exports of marine products & Annual vol. change, $\%$ & $-4,0$ & $-0,7$ & $-2,1$ & $-1,0$ & 1,0 \\
\hline Large-scale industry export & Annual vol. change, $\%$ & 43,3 & 60,7 & 5,2 & 1,0 & 3,0 \\
\hline Total export of goods and services & Annual vol. change, $\%$ & 17,7 & 7,1 & 1,1 & 1,7 & 2,0 \\
\hline Total import of goods and services & Annual vol. change, $\%$ & $-0,7$ & $-18,3$ & $-26,4$ & $-2,3$ & 5,1 \\
\hline \multicolumn{7}{|l|}{ Money and prices } \\
\hline Inflation & $\%$ & 5,0 & 12,4 & 12.0 & 6,0 & 3,1 \\
\hline Exchange rate index & Annual change, $\%$ & $-2,5$ & 40,4 & 34,2 & 5,0 & $-4,0$ \\
\hline Central Bank policy rate & Annual average, $\%$ & 14,3 & 17,1 & 14,9 & 9,1 & 8,3 \\
\hline
\end{tabular}

Sources: Statistics Iceland, Central Bank of Iceland, Directorate of Labour and Ministry of Finance. 


\section{Finland}

\subsection{Den ekonomiska politiken}

I mitten av årtiondet stärktes den offentliga ekonomin kraftigt. Samtidigt förblev den offentliga ekonomins konjunkturrensade finansiella sparande nästan oförändrat. De stimulansåtgärder som man kommit överens om för att lindra följderna av recessionen försämrar däremot det konjunkturrensade finansiella sparandet kraftigt i år och nästa år. Finanspolitiken håller således på att bli klart tillväxtstödjande.

Finlands offentliga ekonomi står inför en svår situation till följd av den ekonomiska krisen. Krisen har kraftigt stramat åt statens skatteinkomster och man har försökt upprätthålla den ekonomiska aktiviteten med flertalet aktivåtgärder från det allmännas sida. Den offentliga skulden har växt kraftigt och den långsiktiga hållbarheten hos den offentliga ekonomins finansiella situation har blivit ett större bekymmer än tidigare. Den kraftigt ökade upplåningen begränsar finanspolitikens spelrum. Ju längre krisen inverkar på den offentliga ekonomin, desto mera tyngd måste man i det finanspolitiska beslutsfattandet ge åt den offentliga ekonomins finansiella situation på bekostnad av andra finanspolitiska mål.

Den offentliga ekonomins finansiella sparande, om sedan 1998 uppvisat överskott, blir i år ordentligt på minus och underskottet fördjupas ytterligare 2010. Hela den offentliga ekonomins finansiella situation beräknas i år försämras med nästan 13 miljarder euro från ifjol, dvs. 7 procentenheter i förhållande till totalproduktionen: Detta är för vår del ett brantare ras än depressionsåret 1991. Grovt taget hälften av förändringen beror hos oss på beslutsbaserade, tillväxtstödjande åtgärder, m.a.o. skattelättnader och utgiftsökningar, hälften på att de konjunkturkänsliga skatteinkomsterna automatiskt minskat och att arbetslöshets- o.d. konjunkturkänsliga offentliga utgifter ökat. Trots att konjunkturutsikterna förbättras något 2010 försämras de offentliga samfundens finansiella situation ytterligare med 3,3 miljarder euro, och den gräns på ett treprocentigt underskott som satts i EU:s stabilitets- och tillväxtpakt överskrids för första gången under Finlands EMU-medlemskap. Finanspolitiken är tillväxtstödjande både i år och nästa år. Hela den offentliga ekonomin beräknas få ett underskott på ca $2 \frac{1}{1} 2$ procent $\mathrm{i}$ förhållande till totalproduktionen $\mathrm{i}$ år. Nästa år den offentliga ekonomin kommer att ha ett underskott på 41/2 procent och skulden stiger till ca $48 \%$ av BNP.

Statsförvaltningens finansiella situation försämras enbart enligt nationalräkenskaperna på ett par år med 7 procentenheter i förhållande till BNP på grund av de beslut om skattelättnader och utgiftsökningar som fattats i stimulanssyfte samt de utgifter som ökar automatiskt under en lågkonjunk- 
tur. Minskningen av skattebasen, dvs. företagens resultat, den privata konsumtionen, kapitalinkomsterna och arbetsinkomsterna realiseras i form av sänkt taxeringsutfall. Statens utgifter fortsätter samtidigt att öka förhållandevis kraftigt. I år underskott i statsfinanserna kommer att vara $4 \frac{112}{2} \%$ i förhållande till bruttonationalprodukten. Nästa års underskott är redan $6 \%$ av BNP och statsskulden beräknas att stiga till $44 \%$ av BNP.

Den kommunala sektorns nettokreditgivning enligt nationalräkenskaperna sjunker i år till -0,5 \% i förhållande till totalproduktionen. Balansutvecklingen 2010 beror i stor utsträckning på kommunernas framtida beslut i anslutning till kommunal- och fastighetsbeskattningen samt dämpandet av utgiftsökningen. Också uppgörelserna i följande löneavtal har en avgörande inverkan på kommunekonomins situation. Trots att utgifterna börjar öka långsammare och statens omfattande åtgärder förblir kommunernas nettokreditgivning $2010-1 / 2 \%$ av BNP.

\subsection{Den ekonomiska utvecklingen}

Den krympta världshandeln samt det stora inslaget av konjunkturkänsliga investeringsförnödenheter i Finlands export har kraftigt påverkat vår exportberoende ekonomiska aktivitet. I början av 2009 har bruttonationalprodukten sjunkit kraftigt. Också i hemlandet har det kommit preliminära bedömningar som säger att recessionen närmar sig botten. Särskilt barometermaterial som beskriver konsumenternas och företagens förväntningar tycks visa tecken på en återhämtning från och med årets andra hälft. Ekonomin förväntas således repa sig mot slutet av året även hos oss. Detta hinner dock inte påverka bedömningen för i år, utan bruttonationalprodukten förutspås krympa i medeltal 6 \% under hela året i Finland. Om ekonomierna i Finlands viktigaste handelspartner återhämtar sig, förutspås vår exportindustri dra med sig vår bruttonationalprodukt så att den nästa år uppvisar en liten ökning på ungefär 0,5 \%. Den långvariga exportunderstödda ekonomiska utvecklingen bröts i och med recessionen. I fjol steg exportens BNP-andel till rekordhöga $47 \%$. Till följd av recessionen har importefterfrågan hos Finlands traditionella handelspartner varit mycket svag. Under årets första hälft minskade värdet av varuexporten med en dryg tredjedel jämfört med motsvarande tidsperiod föregående år. Exporten har dock visat tecken på att börja stabiliseras. Då konjunkturen beräknas vända uppåt i t.ex. Tyskland och Sverige mot slutet av året och normaliseringen av priserna på råvaror stöder en svag återhämtning i Ryssland, finns det grund för en stärkning av Finlands export under årets senare hälft. Ändå kommer exporten i år att krympa med $22 \%$ och även exportpriserna sjunker kännbart. Exportvolymen förutspås öka endast något nästa år, cirka 2 \%.

Importen av råvaror och produktionsförnödenheter minskar kännbart i år och följer tätt utvecklingen av industrins produktions- och exportutsikter. 
Anpassningen av lagren så att de motsvarar efterfrågan bidrar till att minska importen. Importen av maskiner och anordningar minskar kännbart efter företagen skjuter fram sina investeringsprojekt. I år minskar importvolymen med ungefär en femtedel och importpriserna sjunker med nästan 10 \%. År 2010 fortsätter importen att vara lam och minskar med 1 \%. I år sjunker överskottet i bytesbalansen i förhållande till totalproduktionen till cirka 1,5 \% från de senaste 10 årens medeltal på 6 \%. Hushållens konsumtionsutgifter började minska för ett år sedan och minskningstakten tilltog i början av året. Konsumtionen har inskränkts på bred basis, eftersom hushållen har gett avkall på såväl varor som tjänster. Eftersom löntagarnas reallöner ändå steg med nästan 3 \% i början av året jämfört med i fjol har konsumenterna börjat spara avsevärt mera. Å andra sidan fortsatte hushållen att skuldsätta sig under årets första hälft, även om skuldsättningen ökade långsammare än ett år tidigare. På grund av det försämrade sysselsättningsläget ökar inte hushållens sammantagna disponibla realinkomster i år, fast lönerna fortsätter att stiga i genomsnitt och staten har lättat upp inkomstbeskattningen. När sparkvoten samtidigt stiger krymper konsumtionen i år med nästan 3 \%. Köpkraften torde stärkas lite grann nästa år, men när arbetslösheten fortsätter att öka torde hushållens försiktighet hålla i sig och konsumtionen krymper ytterligare något.

Investeringarna minskar med cirka 10 \% i år. Investeringarna minskar inom samtliga fabriksindustribranscher och särskilt inom skogs-, maskinoch metallindustrin är nedgången kraftig. Också bostadsbyggnadsinvesteringarna minskar i år, men sannolikt inte längre nästa år. Investeringarna i anläggningsarbeten minskar i år men börjar öka 2010. Maskin- och anordningsinvesteringarna minskar bägge åren. Allt som allt minskar de totala investeringarna med ytterligare 5-6 \% nästa år. I år minskar industriproduktionen mera än t.ex. depressionsåret 1991. Till följd av den låga exportefterfrågan sjunker industriproduktionen med 15 \% från i fjol. Produktionsraset är omfattande och berör de mest varierande industribranscher, kraftigast ändå skogsindustrin. Också produktionen av tjänster kommer att krympa. Den ökade arbetslösheten och företagens kostnadsnedskärningar minskar efterfrågan på tjänster för såväl konsumenter som industriföretag jämfört med i fjol.

Detta år minskar antalet arbetsplatser framför allt därför att exporten krymper men också för att den inhemska efterfrågan sjunker. Antalet sysselsatta blir mer än 90000 färre än 2008 och sysselsättningsgraden sjunker till under 68 \%. Arbetslöshetsgraden stiger till i medeltal 9 \% i år. År 2010 fortsätter efterfrågan på arbetskraft att minska med ungefär 70 000 personer så att sysselsättningsgraden sjunker ner mot $66 \%$, dvs. samma nivå som för 10 år sedan. Arbetslöshetsgraden stiger till i medeltal 101/2\% och ungefär 280000 personer är arbetslösa. Ett allvarligt problem blir de längre arbetslöshetstiderna och därigenom börjar också den strukturella arbetslösheten öka. Råvarupriserna har varit försiktigt på väg uppåt efter det kraftiga raset under fjolårets senare hälft. Månadsindikato- 
rerna för industrins producent- och importpriser torde så småningom följa råvarornas pristrend. Konsumentpriserna har nästan slutat att stiga och vissa månader sjunker index jämfört med månaden innan. Priserna sjunker fortfarande till följd av billigare låneräntor, bostäder och bränsle, men en vändning kan redan skönjas mot slutet av året. Den skatteförhöjning på alkohol- och tobaksprodukter som genomfördes i början av året höjer prisnivån med knappt 0,5 \%. I oktober höjs skatten på alkohol på nytt medan mervärdesskatten på livsmedel sänks med 5 procentenheter. År 2009 blir den genomsnittliga årsuppgången i konsumentprisindex bara 0,1 \%. År 2010 fortsätter import- och produktionspriserna att stiga behärskat och även arbetskraftskostnaderna kommer att stiga sakta. Bostadspriserna och räntorna sjunker inte längre. Konsumentpriserna förutspås stiga med litet över $1 \%$.

\subsection{Utsikterna på medellång sikt}

På medellång sikt kommer det att bli allt svårare att genom ekonomisk tillväxt skapa överskott inom den offentliga ekonomin, eftersom befolkningsåldrandet börjar begränsa tillväxtmöjligheterna. Den arbetsföra befolkningen börjar minska redan efter innevarande år. Bortfallet bland den arbetsföra befolkningen kommer att vara nästan 90000 personer före 2015. Dessutom kommer den ekonomiska krisen att orsaka allt större press mot den offentliga ekonomin. Befolkningsåldrandet kommer att leda till kraftigt höjda pensionsutgifter under nästa årtionde. Tillräcklig beredskap inför framtida utgiftstryck skulle därför förutsätta ett klart överskott inom de offentliga finanserna på medellång sikt. Den offentliga ekonomins underskott kommer dock på grund av den ekonomiska krisen att öka till $4 \frac{1}{2}$ procent av BNP nästa år, och de offentliga samfundens skuld i förhållande till BNP till över 48 procent. Detta kommer att medföra stora utmaningar för de kommande årens finanspolitik. Man måste finna en lösning för hur man under kommande år minskar på det offentliga underskottet, stödjer förutsättningarna för ekonomisk tillväxt och säkrar den offentliga ekonomins hållbarhet.” 
Tabell 3.1 Nyckeltal för Finlands ekonomi. Procentuell förändring. ${ }^{1)}$

\begin{tabular}{|c|c|c|c|c|}
\hline & Mdr. Euro 2008 & 2008 & 2009 & 2010 \\
\hline \multicolumn{5}{|l|}{ Fasta priser } \\
\hline Hushållens konsumtionsutgifter (=privata) & 96 & 1,9 & $-2,9$ & $-0,3$ \\
\hline Offentliga konsumtionsutgifter & 41 & 2,0 & 1,2 & $-0,1$ \\
\hline Fasta bruttoinvesteringar & 38 & 0,3 & $-10,1$ & $-5,5$ \\
\hline Näringsliv & 23 & 4,5 & $-11,1$ & $-7,7$ \\
\hline Bostäder & 10 & $-9,3$ & $-12,0$ & 0,0 \\
\hline Myndigheter & 5 & $-0,3$ & $-1,5$ & $-6,1$ \\
\hline agerinvesteringar $^{2)}$ & 2 & & & \\
\hline Total inhemsk efterfrågan & 178 & 0,6 & $-4,0$ & $-0,7$ \\
\hline Export & 87 & 7,3 & $-22,0$ & 1,8 \\
\hline Import & 79 & 7,0 & $-19,0$ & $-1,2$ \\
\hline Bruttonationalprodukt & 185 & 1,0 & $-6,0$ & 0,3 \\
\hline Sysselsättning, personer & . & 1,6 & $-3,6$ & $-2,6$ \\
\hline Arbetslöshet (\% av arbetskraften) & . & 6,4 & 9,0 & 10,5 \\
\hline Konsumtionsprisindex & . & 4,1 & 0,1 & 1,2 \\
\hline Lön & . & 5,6 & 4,2 & 3,0 \\
\hline Effektiv valutakurs ${ }^{4)}$ & . & & & \\
\hline Bytesförhållande & . & $-3,3$ & 2,8 & $-1,9$ \\
\hline Bytesbalans (\% av BNP) & . & 2,6 & 1,5 & 2,0 \\
\hline 3-månaders penningmarknadsränta (nivå) & . & 4,8 & 1,5 & 2,0 \\
\hline
\end{tabular}

1) Beräknat i fasta priser, basår 2000.

2) Förändring i \% av föregående års BNP.

3) Löneindex.

4) Positivt tal innebär depreciering

Källor: Statistikcentralen och Finansministeriets ekonomiska avdelning (september 2009) 



\section{Norge}

\subsection{Den økonomiske politikken}

Den norske regjering fører en politikk som bygger på rettferdighet og fellesskap. Med utgangspunkt i den nordiske modellen vil Regjeringen fornye og utvikle de offentlige velferdsordningene og bidra til en mer rettferdig fordeling og et arbeidsliv der alle kan delta. Regjeringen vil legge til rette for økt verdiskaping og utvikling i hele landet, innenfor rammer som sikrer at kommende generasjoners muligheter for å dekke sine behov ikke undergraves. En slik bærekraftig utvikling krever en ansvarlig politikk med vekt på natur- og miljøhensyn, en langsiktig forvaltning av nasjonalformuen, et opprettholdbart pensjonssystem, et velfungerende næringsliv og en sterk offentlig sektor.

Handlingsregelen for budsjettpolitikken innebærer en gradvis innfasing av petroleumsinntektene i norsk økonomi, om lag i takt med utviklingen i forventet realavkastning av Statens pensjonsfond - Utland, anslått til 4 pst. Budsjettpolitikken har dermed en mellomlangsiktig forankring. Samtidig åpnes det for at hensynet til en stabil økonomisk utvikling skal tillegges vekt i den løpende utformingen av budsjettpolitikken.

Pengepolitikken skal sikte mot stabilitet i den norske krones nasjonale og internasjonale verdi. Den operative gjennomføringen av pengepolitikken skal rettes inn mot lav og stabil inflasjon, definert som en årsvekst $\mathrm{i}$ konsumprisene som over tid er nær 2,5 pst. Av forskriften følger det at pengepolitikken skal bidra til å stabilisere utviklingen i produksjon og sysselsetting og til stabile forventninger om valutakursutviklingen. Budsjett- og pengepolitikken må virke sammen for å bidra til en balansert utvikling i norsk økonomi.

En hovedoppgave for den økonomiske politikken gjennom det siste året har vært å bidra til å dempe virkningen av finanskrisen og det internasjonale, økonomiske tilbakeslaget på sysselsetting og arbeidsledighet $\mathrm{i}$ Norge. Det har derfor vært nødvendig å benytte den handlefriheten som ligger i retningslinjene for den økonomiske politikken, for å bidra til en stabil økonomisk utvikling.

Norske myndigheter møtte finanskrisen og det kraftige tilbakeslaget i verdensøkonomien med omfattende tiltak for å bedre forholdene i finansmarkedet og stimulere innenlandsk etterspørsel:

- Da penge- og kredittmarkedene nærmest stoppet opp å fungere i fjor høst, var Regjeringen og Norges Bank raskt ute med ordninger for å tilføre nødvendig likviditet til banksystemet. Allerede i oktober i fjor lanserte Regjeringen «byttelånsordningen» overfor bankene, der 
bankene får låne statspapirer i bytte mot obligasjoner med fortrinnsrett. Senere er det også blitt opprettet andre ordninger - Statens finansfond og Statens obligasjonsfond - som tilbyr banker og næringsliv statlig kapital i en tid der tilgangen på kapital fra ordinære kilder har vært vanskelig.

- Pengepolitikken ble raskt lagt om i ekspansiv retning. Fra oktober i fjor og fram til midten av juni i år senket Norges Bank styringsrenten med 4,5 prosentpoeng, til 1,25 pst. Norges Bank satte opp renten med 0,25 prosentpoeng den 28 . oktober, og har signalisert at renten vil bli satt gradvis opp framover.

- Også budsjettpolitikken ble lagt om i svært ekspansiv retning. Målt ved endringen i det strukturelle oljekorrigerte budsjettunderskuddet kan den finanspolitiske stimulansen fra 2008 til 2009 anslås til 2,7 pst. av trend-BNP for Fastlands-Norge. Dette er den sterkeste ekspansive impulsen på over 30 år.

- Fordi veksten i BNP for Fastlands-Norge anslås å bli lavere enn trendvekst, og arbeidsledigheten ventes å øke noe fra 2009 til 2010, har Regjeringen funnet det riktig med en viss ytterligere økning i bruken av oljeinntekter også i 2010. Det vedtatte budsjettet for 2010 var basert på en økning i bruken av oljeinntekter tilsvarende om lag $1 / 2$ pst. av trend-BNP for Fastlands-Norge.

- Regjeringens forslag til budsjett for 2010 innebærer et strukturelt, oljekorrigert budsjettunderskudd på 148,5 mrd. kroner, som er nesten $45 \mathrm{mrd}$. kroner høyere enn forventet fondsavkastning for 2010. Det er Regjeringens klare målsetting at oljepengebruken bringes tilbake til 4-prosentbanen etter hvert som utsiktene bedres og veksten i norsk økonomi tar seg opp.

\subsection{Den økonomiske utviklingen}

Etter flere år med sterk vekst passerte norsk økonomi en konjunkturtopp rundt årsskiftet 2007/2008. Den internasjonale finanskrisen og tilbakeslaget i verdensøkonomien forsterket konjunkturnedgangen mot slutten av fjoråret. Lavere vekst hos handelspartnerne og fall i etterspørselen etter viktige norske eksportprodukter ga lavere produksjon og inntjening for eksportrettede virksomheter. Tiltakende pessimisme og strammere kredittilgang forsterket nedgangen i privat konsum og boliginvesteringer, noe som bl.a. trakk aktiviteten innen bygg- og anleggsnæringen markert ned. Etter en svak utvikling i første halvår, falt BNP for Fastlands-Norge mot slutten av fjoråret og inn i inneværende år. Rentenedsettelsene fra Norges Bank og de finanspolitiske tiltakene har gitt sterke impulser til innenlandsk etterspørsel. Høy vekst i offentlig etterspørsel og privat konsum bidro til at nedgangen i BNP for Fastlands-Norge ble snudd til oppgang i 2. kvartal i år. I 3. kvartal tok også eksporten av tradisjonelle varer seg 
opp, og veksten i BNP for Fastlands-Norge tiltok fra 0,3 pst. i 2. kvartal til 0,5 pst. i 3. kvartal. . Sammen med en gunstig næringsstruktur har myndighetenes tiltak bidratt til at Norge har blitt vesentlig mildere rammet av finanskrisen og det internasjonale tilbakeslaget enn de fleste andre land. Arbeidsledigheten er på noe over 3 pst., som fortsatt er relativt lavt historisk sett, og produksjonsnedgangen har vært klart mer begrenset i Norge enn hos våre handelspartnere.

Myndighetenes tiltak rettet mot finansmarkedet har fungert etter hensikten. Risikopremiene har falt og kredittflyten har tatt seg opp. Norges Banks utlånsundersøkelse viser at bankene lettet noe på sin kredittpraksis overfor foretak i 3. kvartal 2009, etter kraftig innstramming siden 4. kvartal 2007. Kredittpraksisen overfor husholdninger har ifølge undersøkelsen vært stabil siden nyttår, etter innstramming gjennom fjoråret. Utviklingen i renter og aksjekurser tyder på at markedsaktørene nå ser lysere på den videre økonomiske utviklingen.

Den kraftige rentenedgangen og økt optimisme har bidratt til et klart omslag i husholdningenes etterspørsel. Ettersom mange husholdninger i Norge eier sin egen bolig er gjeldsgraden i norske husholdninger høy i internasjonal sammenheng. Samtidig er en stor andel av gjelden tatt opp med flytende rente. Renteendringer slår dermed raskt og kraftig ut i husholdningenes kjøpekraft. Etter å ha falt gjennom fjoråret og i 1. kvartal i år, økte det private konsumet i både 2. og 3. kvartal. Ny kortidsstatistikk tyder på at denne utviklingen fortsetter inn i 4 . kvartal. I Nasjonalbudsjettet 2010 er privat konsum anslått å øke med 1/4 pst. i 2009 og med 4 pst. i 2010. Også i boligmarkedet har etterspørselen tatt seg klart opp, med økt omsetning og markert oppgang i boligprisene.

Offentlig etterspørsel bidrar nå med sterke vekstimpulser til økonomien, både gjennom økt sysselsetting og aktivitet i offentlig sektor og gjennom at vedlikeholds- og investeringsprosjekter bidrar til økt aktivitet i bygg- og anleggssektoren. I Nasjonalbudsjettet 2010 er offentlig konsum anslått å øke med 51⁄2 pst. i 2009 og 2 pst. i 2010. Samtidig legges det til grunn en økning i offentlige bruttoinvesteringer på $13^{1 / 4}$ pst. i år og en nedgang på 2 pst. neste år.

Næringsstrukturen i norsk økonomi ga oss et relativt sett gunstig utgangspunkt i møte med finanskrisen og tilbakeslaget internasjonalt. Oljeserviceselskapene, deler av norsk industri og deler av tjenestesektoren har nytt godt av at aktiviteten i petroleumsnæringen har holdt seg høy. Samtidig har vi relativt sett mindre produksjon av industrielle ferdigvarer enn land som har blitt vesentlig hardere rammet av etterspørselssvikt internasjonalt enn Norge. Mens industriproduksjonen i Norge falt med knapt 8 pst. fra august 2008 til august 2009, gikk industriproduksjonen i eurosonen ned med vel 16 pst. Også framover vil aktiviteten i petroleumsnæringen og utviklingen i oljeinvesteringene være viktig for det samlede aktivitetsnivået i norsk økonomi. I Nasjonalbudsjettet 2010 er oljeinvesteringene anslått å øke med 7 pst. i år og 3 pst. neste år. Investe- 
ringene i fastlandsbedriftene er anslått å falle med om lag 161/2 pst. i 2009 og $2 \frac{1}{2}$ pst. i 2010, men selv med en nedgang i denne størrelsesorden vil investeringsnivået som andel av den samlede verdiskapingen i fastlandsbedriftene fortsatt være høyere enn vi har sett ved tidligere konjunkturtilbakeslag.

Også i Norge har imidlertid flere eksportrettede næringer merket svikt i etterspørselen og markert nedgang i utsalgspriser. Utsiktene er imidlertid lysere nå enn for bare kort tid tilbake. Etter å ha falt med hele 16,4 pst. fra 2. kvartal i fjor til 2. kvartal i år, gikk eksportvolumet av tradisjonelle varer sesongjustert opp med 6,6 pst. fra 2. til 3. kvartal. Oppgangen i 3 kvartal skyldes høy vekst i eksporten av verkstedsprodukter, metaller og nærings- og nytelsesmidler. I Nasjonalbudsjettet 2010 er det anslått en nedgang i eksportvolumet av tradisjonelle varer på 11 pst. i år og en oppgang på $1 \frac{1}{2} 2$ pst. neste år.

Samlet sett anslås det i Nasjonalbudsjettet 2010 at BNP for FastlandsNorge vil falle med vel 1 pst. i 2009 for deretter å øke med vel 2 pst. i 2010. Statistikk som er kommet etter framleggelsen av budsjettet er samlet sett godt i tråd med anslagene. Usikkerheten knyttet til den videre økonomiske utviklingen er imidlertid fortsatt stor, og større for enkeltnæringer enn for økonomien sett under ett. Selv om vi framover venter høyere vekst i internasjonal økonomi, står eksportvirksomhetene trolig overfor utfordrende tider ennå en tid.

Omslaget i norsk økonomi har gitt seg utslag i en klar avdemping i arbeidsmarkedet, med nedgang i sysselsetting og økt arbeidsledighet. Svekkelsen av arbeidsmarkedet har likevel ikke blitt så sterk som mange fryktet. Ifølge Arbeidskraftsundersøkelsen (AKU) utgjorde arbeidsledigheten 3,1 pst. av arbeidsstyrken i 3. kvartal, opp 0,7 prosentpoeng fra 3. kvartal i fjor. Sysselsettingsutviklingen har imidlertid variert mye mellom ulike næringer det siste året. Mens sysselsettingsveksten innen offentlig sektor har vært sterk, har det vært betydelig nedgang innen enkelte næringer i privat sektor. Det er også en tendens til at flere blant unge og eldre aldersgrupper nå trekker seg ut av eller utsetter sin inntreden i arbeidsmarkedet. Etter sterk vekst i arbeidsinnvandringen de siste årene er det tegn til at færre nå kommer til Norge for å arbeide.

I Nasjonalbudsjettet 2010 ble det lagt til grunn en samlet nedgang i sysselsettingen på 10000 personer på årsbasis, eller knapt 1/2 pst., både i 2009 og 2010. Med en moderat oppgang i arbeidsstyrken ble arbeidsledigheten anslått til knapt 31/4 pst. som gjennomsnitt for inneværende år og knapt 33/4 pst. i 2010.

Et mindre stramt arbeidsmarked enn i de foregående årene og fortsatt usikkerhet i flere næringer ventes å bidra til noe lavere pris- og lønnsvekst framover. Samtidig ventes prisene på importerte konsumvarer å avta noe som følge av kronestyrkingen siden i vår og den lave konsumprisveksten hos handelspartnerne. I Nasjonalbudsjettet 2010 er konsumprisindeksen (KPI) anslått å øke med 1,8 pst. både 2009 og 2010, mens 
veksten i konsumprisene justert for avgifter og utenom energivarer (KPIJAE) anslås til henholdsvis 2,5 og 1,6 pst. i de to årene. Lønnsveksten er anslått å avta fra 6 pst. i 2008 til henholdsvis 4 og 31⁄2 pst. i 2009 og 2010.

\subsection{Utsiktene på mellomlang sikt}

BNP for Fastlands-Norge økte med $43 / 4$ pst. i gjennomsnitt per år i den kraftige oppgangskonjunkturen i perioden 2004-2007, dvs. 1 3/4 prosentpoeng mer enn gjennomsnittet for årene fra 1970 til 2008. Det var særlig arbeidsinnsatsen som økte sterkt i denne fireårsperioden, bl.a. som følge av høy arbeidsinnvandring.

Konjunkturnedgangen vi nå er inne i ventes å føre til et fall i utførte timeverk i år og neste år. Samtidig tyder foreløpige tall fra nasjonalregnskapet på svak produktivitetsvekst i år. Videre fram mot 2012 er det $\mathrm{i}$ Nasjonalbudsjettet 2010 lagt til grunn at veksten i timeverkene tar seg opp til et nivå om lag på linje med det historiske gjennomsnittet på 1/2 pst. per år. Med en produktivitetsvekst i fastlandsøkonomien på i størrelsesorden $1 \frac{1}{2}-2$ pst. er veksten i BNP for Fastlands-Norge anslått til om lag 21/2 pst. per år fram til og med 2012.

Oljeinvesteringer anslås å avta noe i årene framover og det legges til grunn begrensede impulser fra den økonomiske politikken. Rentenivået vil gradvis måtte normaliseres, og bruken av petroleumsinntekter vil måtte bringes ned mot 4-prosentbanen etter hvert som den økonomiske situasjonen bedres. Ledigheten ventes å stabilisere seg på et nivå godt under det gjennomsnittlige nivået for de siste 20 årene, men noe høyere enn det vi har sett de siste årene. 
Tabell 4.1 Nøkkeltall for norsk økonomi. Prosentvis endring fra året før ${ }^{1}$

\begin{tabular}{|c|c|c|c|c|}
\hline & Mrd kroner $^{2}$ & & & \\
\hline & 2008 & 2008 & 2009 & 2010 \\
\hline Privat konsum & 987,3 & 1,3 & 0,3 & 4,0 \\
\hline Offentlig konsum & 491,8 & 4,1 & 5,6 & 2,1 \\
\hline Bruttoinvesteringer i fast kapital & 542,1 & 1,4 & $-5,9$ & $-1,0$ \\
\hline Herav:Oljeutvinning og rørtransport & 122,2 & 3,7 & 7,0 & 3,0 \\
\hline Bedrifter i Fastlands-Norge & 226,2 & 6,1 & $-16,4$ & $-2,6$ \\
\hline Boliger & 93,4 & $-12,1$ & $-12,0$ & 0,5 \\
\hline Offentlig forvaltning & 78,8 & 4,7 & 13,2 & $-2,0$ \\
\hline Lagerendring $^{3}$ & 34,7 & 0,5 & $-0,6$ & 0,0 \\
\hline Total innenlandsk etterspørsel & 2056,0 & 2,5 & $-0,7$ & 2,3 \\
\hline Etterspørsel fra Fastlands-Norge (utenom lagerendring) & 1877,5 & 1,9 & $-0,3$ & 2,4 \\
\hline Eksport & 1222,6 & 0,9 & $-6,5$ & 0,1 \\
\hline Herav: Råolje og naturgass & 620,5 & $-2,0$ & $-4,4$ & $-2,1$ \\
\hline Tradisjonelle varer & 322,9 & 4,3 & $-11,0$ & 1,6 \\
\hline Import & 735,4 & 2,2 & $-4,9$ & 2,4 \\
\hline Herav: Tradisjonelle varer & 477,1 & $-0,4$ & $-7,1$ & 1,9 \\
\hline Bruttonasjonalprodukt & 2543,2 & 1,8 & $-2,1$ & 1,3 \\
\hline Herav: Fastlands-Norge & 1818,0 & 2,2 & $-1,1$ & 2,1 \\
\hline Fastlands-Norge uten el.forsyning & 1760,9 & 2,2 & $-0,7$ & 1,9 \\
\hline \multicolumn{5}{|l|}{ Andre nøkkeltall: } \\
\hline Sysselsetting, personer & & 3,1 & $-0,4$ & $-0,4$ \\
\hline Arbeidsledighetsrate, AKU (nivå) & & 2,6 & 3,2 & 3,7 \\
\hline Konsumprisindeksen (KPI) & & 3,8 & $13 / 4$ & $13 / 4$ \\
\hline KPI-JAE & & 2,6 & $2 \frac{1}{2}$ & $1 \frac{1}{2}$ \\
\hline Årslønn & & 6,0 & 4 & $3 \frac{1}{2}$ \\
\hline Effektiv valutakurs (Konkurransekursindeksen) ${ }^{4}$ & & $-0,5$ & 3,8 & 0,0 \\
\hline Bytteforholdet overfor utlandet, totalt & & 12,0 & $-18,0$ & 1,8 \\
\hline Bytteforholdet overfor utlandet, tradisjonelle varer & & $-2,1$ & $-5,8$ & 0,5 \\
\hline Råoljepris, kroner pr. fat ${ }^{2}$ & & 536 & 375 & 425 \\
\hline Driftsbalansen (pst. av BNP) & & 19,5 & 12,0 & 12,2 \\
\hline
\end{tabular}

1) Tallene for 2008 er beregnet i faste 2007-priser, tallene for 2009 og 2010 er beregnet i faste 2006-priser.

2) Løpende priser. Reviderte nasjonalregnskapstall ble publisert 24.11.09.

3) Endring i prosent av BNP året før.

4) Et positivt endringstall innebærer en svekkelse av norske kroner.

Kilder: Statistisk sentralbyrå og Finansdepartementet. 


\section{Sverige}

\subsection{Den ekonomiska politiken}

Ett trovärdigt finanspolitiskt ramverk med tydliga mål och restriktioner bidrar till en väl utformad finanspolitik. En stram budgetprocess, införandet av ett överskottsmål för den offentliga sektorn, ett utgiftstak för staten och ett kommunalt balanskrav har varit avgörande för att öka trovärdigheten för den ekonomiska politiken i Sverige. Det finanspolitiska ramverket syftar både till långsiktig hållbarhet och till att hindra finanspolitiken från att utformas så att den riskerar att bli kortsiktigt destabiliserande. Ramverket syftar också till att Sverige som EU-medlem ska efterleva Stabilitets- och tillväxtpaktens regler.

Mot bakgrund av att de åldersrelaterade offentliga utgifterna framöver kommer att öka markant anser regeringen att överskottsmålet på $1 \%$ av BNP över en konjunkturcykel bör upprätthållas så länge det är nödvändigt för att de offentliga finanserna ska utvecklas på ett långsiktigt uthålligt sätt. Ett överskottsmål bidrar också till att det finns en viss buffert för att kunna möta kraftigare nedgångar i konjunkturen. Utgiftstakets främsta uppgift är att ge förutsättningar att uppnå överskottsmålet. Utgiftstaket utgör ett viktigt budgetpolitiskt åtagande som främjar budgetdisciplinen och stärker trovärdigheten i den ekonomiska politiken. Genom att utgiftstaket sätts för flera år förhindras att tillfälliga inkomster används för att finansiera varaktiga utgifter. Utgiftstaket understryker även behovet av prioriteringar mellan olika utgifter och förebygger en utveckling där skatteuttaget stegvis måste höjas till följd av bristfällig utgiftskontroll.

De offentliga finanserna har förstärkts påtagligt under de år ramverket har varit i kraft. Underskotten på 1990-talet har ersatts av ett genomsnittligt överskott under perioden 2000-2007 på 1,6 procent av BNP. Den kraftiga och snabba försämringen av den ekonomiska utvecklingen medför dock att den offentliga sektorn som helhet beräknas uppvisa underskott i finansiellt sparande samtliga år 2009-2012. Det finansiella sparandet bedöms uppgå till -2,2 procent av BNP 2009 och -3,4 procent av BNP 2010. Underskottet i det finansiella sparandet ligger nästan helt i staten. Det beror framför allt på den svaga utvecklingen av skatteintäkterna och de ökade utgifterna för arbetsmarknadsrelaterade utgifter. Kommunsektorn redovisar såväl ett negativt finansiellt sparande som ett negativt resultat 2009. Nästa år bidrar höjda statsbidrag till balans i det finansiella sparandet samtidigt som resultatet för sektorn som helhet väntas bli positivt.

I september 2003 genomfördes en folkomröstning om Sverige skulle införa euron som valuta. Resultatet av folkomröstningen föranledde inga förändringar i penning- och valutapolitiken. Regeringen har ansvaret för 
övergripande valutapolitiska frågor och Riksdagen beslutar om växelkurssystemet medan Riksbanken ansvarar för tillämpningen av växelkurssystemet.

Riksbanken har preciserat ett explicit inflationsmål som innebär att den årliga förändringen av konsumentprisindex (KPI) ska vara 2 procent med ett toleransintervall på plus/minus 1 procentenhet. Om avvikelser från inflationsmålet uppstår är ambitionen normalt att föra inflationen tillbaka till målet inom två år. Ett skäl till det är att penningpolitiken verkar med fördröjning. Ett annat är att tvåårshorisonten bidrar till att dämpa fluktuationerna i realekonomin samtidigt som trovärdigheten för inflationsmålet bevaras. Undantagsvis kan Riksbanken låta anpassningen till inflationsmålet ta längre tid än två år. När Riksbanken bedömer att det uppstår en sådan situation ska detta tydligt klargöras i samband med de penningpolitiska besluten.

\subsection{Den ekonomiska utvecklingen}

Den kraftiga nedgången i världskonjunkturen har drabbat den svenska ekonomin hårt. Den senaste tidens positiva utveckling på de finansiella marknaderna och förbättrade stämningsläge pekar dock på att konjunkturen är på väg att vända uppåt, såväl i omvärlden som i Sverige. Förtroendeindikatorer för företag och hushåll visar att stämningsläget i den svenska ekonomin fortfarande är svagare än normalt med att pessimismen minskat. För helåret 2009 beräknas svensk BNP falla med 5,2 procent. BNP-nivån bedöms vara som lägst under första kvartalet 2010 för att därefter öka. Bakom uppgången ligger en stabilisering av efterfrågan från omvärlden och en expansiv finans- och penningpolitik.

Återhämtningen väntas dock gå långsamt. Den främsta anledningen är att lågkonjunkturen är global och att exportindustrin därmed har svårt att dra igång den svenska ekonomin. Det låga kapacitetsutnyttjandet i omvärlden hämmar dessutom svensk export som till stor del består av investeringsvaror och insatsvaror. Även den inhemska efterfrågan utvecklas svagt. Den djupa nedgången på arbetsmarknaden och den svaga utvecklingen av disponibelinkomsten begränsar den privata konsumtionen även om de automatiska stabilisatorerna och regeringens aktiva åtgärder för att stimulera efterfrågan dämpar krisens effekter på den inhemska efterfrågan. Konjunkturnedgången har också resulterar i ett mycket lågt kapacitetsutnyttjande som, i kombination med den fortsatt svaga efterfrågan från både svenska och utländska konsumenter, leder till att företagens investeringsbehov är begränsat.

Det försämrade konjunkturläget syns allt tydligare på arbetsmarknaden. Antalet sysselsatta har minskat med ca 100000 personer det senaste året och indikatorer på arbetsmarknadsläget tyder på ett fortsatt fall i sysselsättningen under resten av 2009. Det kraftiga fallet i efterfrågan sedan 
hösten 2008 har medfört att företagen ännu inte hunnit med att anpassa personalstyrkan till den mycket låga produktionsnivån. En fortsatt anpassning av arbetsstyrkan i kombination med en svag återhämtning av produktionen innebär att efterfrågan på arbetskraft utvecklas mycket svagt de närmaste åren. Sysselsättningen i hela ekonomin bedöms falla kraftigt 2009 och 2010 för att stabiliseras kring årsskiftet 2010/2011. Den kraftiga nedgången i antalet sysselsatta, tillsammans med ett förhållandevis högt arbetskraftsdeltagande, resulterar i att arbetslösheten stiger under de närmaste åren.

Det kraftiga fallet i efterfrågan har medfört att resursutnyttjandet på arbetsmarknaden har minskat snabbt sedan 2008, något som illustreras i att arbetskraftsbristen enligt Konjunkturinstitutets barometer sjunkit snabbt. Resursutnyttjandet på arbetsmarknaden bedöms bli mycket lågt de närmaste åren. Sysselsättningen har fallit kraftigt, vilket innebär att många är arbetslösa. Samtidigt finns det mycket ledig kapacitet inom företagen eftersom de inte fullt ut har hunnit anpassa personalstyrkan och maskinparken till den låga produktionsnivån efter det kraftiga fallet under hösten 2008 och inledningen av 2009. I takt med att produktionsnivån börjar återhämta sig finns det således i första hand mycket ledig kapacitet inom företagen samtidigt som det finns många arbetssökande. Därmed blir resursutnyttjandet i ekonomin som helhet starkt negativt 2009 och 2010.

Avtalsrörelsen 2010 förväntas resultera i historiskt låga löneökningar på grund av det fortsatt svaga arbetsmarknadsläget. Trots nedväxlingen i nominell löneökningstakt fortsätter de reala lönerna att öka med i genomsnitt ca 1 procent per år under nästa avtalsperiod eftersom inflationen förväntas bli mycket låg. Inflationen, beräknad som årlig procentuell förändring av konsumentprisindex (KPI), har fallit snabbt sedan hösten 2008 och förväntas sjunka till historiskt låga tal under hösten 2009 för att därefter vända uppåt. Nedgången beror framför allt på lägre räntekostnader för egnahem samt lägre energikostnader. Även det underliggande inflationstrycket bedöms vara mycket lågt de närmaste åren.

\subsection{Utsikterna på medellång sikt}

På längre sikt styrs BNP i högre grad av hur ekonomins utbudssida utvecklas. Utbudssidan bedöms utvecklas i god takt framöver och bidrar till att förutsättningarna är goda för en stark tillväxt när efterfrågan väl tar fart. Trots en stark återhämtning 2011 och 2012, då faktisk BNP ökar betydligt snabbare än potentiell BNP, är resursutnyttjandet i ekonomin fortfarande lågt 2012. Från och med andra halvåret 2011 stiger sysselsättningen igen, när företagen behöver öka antalet anställda i för att möta den ökande efterfrågan i ekonomin. Den kraftiga nedgången i antalet sysselsatta, tillsammans med ett förhållandevis högt arbetskraftsdeltagande, resulterar i att arbetslösheten stiger under de närmaste åren. År 2011 vän- 
tas arbetslösheten vara som högst och uppgå till 11,6 procent. När sysselsättningen successivt ökar igen från och med andra halvåret 2011 börjar arbetslösheten minska.

Tabell 5.1 Nyckeltal för Sveriges ekonomi. Procentuell förändring ${ }^{1)}$

\begin{tabular}{|c|c|c|c|c|}
\hline & Mdr. Kronor 2008 & 2008 & 2009 & 2010 \\
\hline \multicolumn{5}{|l|}{ Fasta priser } \\
\hline Hushållens konsumtionsutgifter & 1467 & $-0,2$ & $-1,8$ & 1,2 \\
\hline Offentliga konsumtionsutgifter & 834 & 1,5 & 1,2 & 1,1 \\
\hline Fasta bruttoinvesteringar & 615 & 2,7 & $-16,6$ & $-6,6$ \\
\hline Näringsliv, exkl. bostäder & 421 & 4,6 & $-21,2$ & $-8,9$ \\
\hline Bostäder & 98 & $-5,4$ & $-22,8$ & 0,1 \\
\hline Myndigheter & 96 & 4,0 & 10,3 & $-4,1$ \\
\hline Lagerinvesteringar $^{2)}$ & 5 & $-0,6$ & $-0,7$ & 0,4 \\
\hline Total inhemsk efterfrågan & 2922 & 0,2 & $-4,8$ & 0,1 \\
\hline Export & 1711 & 1,8 & $-15,3$ & 2,2 \\
\hline Import & 1477 & 3,0 & $-16,1$ & 1,3 \\
\hline Bruttonationalprodukt & 3157 & $-0,2$ & $-5,2$ & 0,6 \\
\hline Sysselsättning, personer & . & 1,2 & $-2,6$ & $-3,5$ \\
\hline Arbetslöshet (\% av arbetskraften) & $\ldots$ & 6,2 & 8,8 & 11,4 \\
\hline Konsumtionsprisindex ${ }^{3)}$ & . & 3,4 & $-0,4$ & 0,4 \\
\hline Lön ${ }^{4)}$ & . & 4,4 & 3,2 & 2,2 \\
\hline Effektiv valutakurs & . & 1,5 & 12,5 & $-2,5$ \\
\hline Bytesförhållande & . & $-0,1$ & 0,8 & $-0,7$ \\
\hline Bytesbalans (\% av BNP). & . & 7,8 & 7,2 & 7,1 \\
\hline 6-månaders penningmarknadsränta (nivå) & . & 3,8 & 0,4 & 0,4 \\
\hline
\end{tabular}

1) Beräknat i fasta priser, referensår 2008.

2) Förändring i \% av föregående års BNP.

3) Konsumentprisindex (KPI)

4) Löneindex, procentuell förändring enligt Nationalräkenskapernas definition.

Källor: Statistiska centralbyrån och Budgetpropositionen för 2010. 


\section{Danmark}

\subsection{Den økonomiske politik}

Finanspolitikken tilrettelægges som udgangspunkt efter den flerårige økonomiske plan Mod nye mål - Danmark 2015. 2015-planen sigter blandt andet på at sikre finanspolitisk holdbarhed, således at velfærdssamfundet også kan finansieres på langt sigt, uden at der fremkommer et behov for større fremtidige finanspolitiske stramninger. Desuden lægges i planen vægt på en stabilitetsorienteret økonomisk politik, der understøtter fastkurspolitikken, og en løbende indsats for at styrke arbejdsudbud og produktivitet.

Det seneste års tid har fokus i den økonomiske politik i høj grad været på at inddæmme virkningerne af den internationale økonomiske og finansielle krise. Dansk økonomi blev ramt hårdt af den globale krise, både via pres på kronen, svækkede eksportmuligheder og nedgang i den indenlandske efterspørgsel, blandt andet som følge af fald i aktiekurser og boligpriser. Faldet i BNP siden starten af 2008 og frem til først halvår 2009 er af samme størrelse som i Sverige og Tyskland, mens nedgangen i bruttoværditilvæksten er noget mindre (som følge af at faldet i BNP i højere grad er drevet af nedgang i det afgiftstunge privatforbrug).

Der er gennemført en række indgreb i den finansielle sektor for at genoprette finansiel stabilitet og tilliden i og til det finansielle system. Initiativerne omfatter garantier for simple kreditorer i danske banker og kapitalindskud i finansielle institutioner (på markedslignende vilkår) og omfattende likviditetsstøtte, blandt andet via en forlængelse af kredittiderne for danske virksomheder. Samtidig har nedsættelsen af indkomstskatterne med 9 mia. kr. i begyndelsen af i år og frigivelsen af SP-midlerne styrket husholdningernes økonomi og dermed bidraget til at stabilisere det private forbrug. I 2009 er der endvidere planlagt fremrykning af offentlige investeringer blandt andet på kommunale kerneområder og på trafikområdet, og der er etableret en pulje til renovering af private boliger. Endelig er der en relativt høj vækst i de offentlige serviceudgifter.

Hertil kommer i 2010 et yderligere løft af de offentlige investeringer samt en markant sænkelse af skatten på arbejdsindkomst i 2010 som led i aftalen om Forårspakke 2.0. Senest sker der med aftalen om finansloven for 2010 yderligere fremrykning og igangsætning af offentlige investeringer for omkring 5 mia. kr. over nogle år, en fortsat forlængelse af virksomhedernes kredittider samt frigivelse af opsparede midler på selvpensioneringskonti.

Provenuvirkningen fra den diskretionære finanspolitik i 2009 og 2010 skønnes til ca. 31/4 pct. af BNP i 2010. Den planlagte vækst i de offentlige 
investeringer i disse år er højere end i andre OECD-lande. Desuden er Danmark et af de lande, hvor der via de offentlige finanser udgår de største automatiske bidrag til at stabilisere den økonomiske aktivitet - dvs. lempelser af finanspolitikken, som automatisk træder i kraft uden nye politiske beslutninger.

I tilrettelæggelsen af finanspolitikken i den nuværende konjunktursituation sigtes efter at balancere mellem tre overordnede hensyn:

For det første bidrager finanspolitikken til at understøtte aktiviteten og beskæftigelsen og dermed dæmpe stigningen i ledigheden på kort sigt. Det hensyn tilgodeses med den nuværende finanspolitik. Samlet set skønnes det, at den økonomiske politik - inklusive det store rentefald siden 2008 - under normale forhold kan løfte beskæftigelsen med ca. 80.000 personer i 2010. Virkningerne af de tiltag, der allerede er besluttet, slår igennem med stigende styrke i år og næste år.

For det andet er det centralt at undgå unødigt store forringelser af de offentlige finanser, fordi det vil øge gælden og rentebetalingerne og derigennem lægge pres på mulighederne for at håndtere de demografiske udfordringer uden mærkbare forringelser af de offentlige ydelser. For store offentlige underskud vil øge sårbarheden overfor nye tilbageslag eller fornyet finansiel uro. Jo mere finanspolitikken lempes i 2010, desto mere skal der strammes i de efterfølgende år, hvor der ikke er sikkerhed for, at opsvinget er robust - og hvor ledigheden risikerer at være højere end i dag. For store underskud og gæld risikerer også at svække tilliden til den økonomiske politik og medføre højere rente til skade for boligmarkedet og beskæftigelsen. Samtidig har omfattende garantier og kapitalindskud i banker mv. medført, at det offentlige er mere eksponeret overfor den finansielle sektor. Det kræver større ansvarlighed i finanspolitikken, når man som Danmark fører fastkurspolitik og ikke deltager i euroen.

For det tredje er lønkonkurrenceevnen under pres, hvilket kan svække vækst- og beskæftigelsesmulighederne på mellemfristet sigt. Konkurrenceevnen er svækket mærkbart siden årtusindeskiftet især som følge af relativt høje danske lønstigninger og en svag produktivitetsudvikling, og igennem det seneste år har inflationen været højere end i euroområdet. Det ventes også at være tilfældet i 2009 og 2010, selv om lønstigningerne i Danmark tager af. Efter den stærke højkonjunktur kan en periode, hvor ledigheden er større end det strukturelle niveau, være den eneste mekanisme, som kan genoprette konkurrenceevnen. Mere ekspansiv finanspolitik risikerer at forstærke sådan en tendens.

\subsection{Udviklingen i dansk økonomi}

Svækkelsen af verdensøkonomien synes at være bremset op og afløst af en vis fremgang. Sammen med de markante lempelser af den økonomiske politik skaber det grobund for en fornyet fremgang i dansk økono- 
mi, og i 3. kvartal steg BNP med godt $1 / 2$ pct. Vendingen i dansk økonomi er dog kommet senere end i fx Sverige og Tyskland, hvor BNP steg allerede i 2. kvartal.

Gennem sidste del af 2009 vurderes aktiviteten i dansk økonomi gradvis at være øget, primært trukket af det private forbrug, eksporten og gradvist ophør af lagernedbringelserne. Stabiliseringen og fornyet vækst i efterspørgslen i 2. halvår 2009 understøttes af fremgang i BNP i udlandet og opgang i verdenshandlen. Samtidig er der tegn på en stabilisering af boligmarkedet i 2./3. kvartal, som kan medvirke til at vende udviklingen i privatforbruget. Forholdene på de finansielle markeder er forbedret, med en klar indsnævring af risikopræmierne, og det pengepolitiske rentespænd er normaliseret.

BNP ventes at vokse yderligere, moderat i 2010, navnlig i kraft af større privatforbrug, opgang i eksporten og høj vækst i de offentlige investeringer. For året som helhed ventes en BNP-vækst på godt 11/4 pct. efter et fald i 2009 på godt 41/4 pct. Væksten er helt overvejende en konsekvens af den økonomiske politik i Danmark og andre lande, herunder de lavere renter. I 2011 ventes yderligere fremgang med en vækst i BNP på godt 11/2 pct.

De nedadgående risici til konjunkturbilledet knytter sig til virkningen på forbrugertillid mv. af den stigende ledighed, konsolideringsbehovet $\mathrm{i}$ banksektoren i lyset af udviklingen i konkurser og tvangsauktioner mv. samt stigende renter og tilbageholdenhed i forbrugs- og investeringsbeslutninger med baggrund i de store offentlige underskud. Desuden er der risiko for, at svækkelsen af konkurrenceevnen medfører større markedsandelstab end forudsat, hvilket vil forlænge perioden med relativt høj ledighed. Omvendt er det også en realistisk mulighed, at der sker en kraftigere aktivitetsfremgang i 2010 som følge af kraftigere gennemslag af den økonomiske politik og en mere markant opbremsning i 2011 i takt med tilbagerulningen af finans- og pengepolitiske lempelser i Danmark og udlandet.

Ledigheden ventes at stige med aftagende styrke frem mod slutningen af 2010. Ledigheden stiger som følge af lav vækst i efterspørgslen gennem det seneste år og i første del af 2009. Desuden har produktivitetsudviklingen været svag, i nogen grad som følge af det uventet store efterspørgselsbortfald i efteråret.

Lønstigningerne i den private sektor ventes at falde men vil formentlig fortsat være større end det (handelsvægtede) gennemsnit for udlandet, og den kraftige forværring af lønkonkurrenceevnen siden årtusindeskiftet bliver derfor fastholdt eller svagt skærpet. Også forbrugerprisinflationen ventes fortsat at være over euroområdets.

De markante lempelser af finanspolitikken og de kraftige automatiske stabilisatorer, sammen med faldet især i de korte markedsrenter til et lavt niveau, er den primære årsag til fornyet fremgang. Modstykket til lempelserne af finanspolitikken og de automatiske stabilisatorer er et markant omsving i de offentlige finanser. De offentlige finanser ventedes således i 
status for konjunkturbilledet fra oktober at blive svækket markant fra et overskud på knap 31/2 pct. af BNP i 2008 til et underskud på 51/2 pct. af BNP i 2010. Det betyder i givet fald overskridelse af grænsen i Stabilitets- og Vækstpagten. I 2011 er forudsat en vis forbedring af de offentlige finanser i takt med øget økonomisk aktivitetet og gradvis tilbagerulning af de markante finanspolitiske lempelser.

\subsection{Udsigterne på mellemlangt sigt}

Den økonomiske politik sigter generelt mod en høj og stabil beskæftigelse, gode rammevilkår for vækst og en holdbar udvikling i de offentlige finanser. Den internationale finansielle krise og de økonomisk-politiske reaktioner på krisen har skærpet de langsigtede finanspolitiske udfordringer. Udgangspunktet er fortsat at opnå strukturel balance på de offentlige finanser i 2015. Det skønnes aktuelt, at det strukturelle underskud er ca. 11/2 pct. af BNP i 2010.

Kravet til forbedringer af den strukturelle saldo frem mod 2015 skal blandt andet ses i lyset af, at de lempelser, der er besluttet for 2009 og 2010 er af midlertidig karakter. Det gælder blandt andet fremrykningen af de offentlige investeringer samt skattereformen, der er underfinansieret i starten, men som samlet styrker saldoen i 2015 i takt med, at finansieringselementerne indfases i overensstemmelse med vedtaget lovgivning. I 2015-forløbet er endvidere forudsat strukturreformer, der styrker den offentlige saldo med ca. 3/4 pct. af BNP frem mod 2015, hvoraf knapt halvdelen skønnes indfriet af de ventede virkninger på arbejdsudbud mv. af skattereformen i Forårspakke 2.0. Udfordringen skal endvidere ses i lyset af, at fremskrivningen i KP08 forudsætter, at den strukturelle ledighed frem mod 2015 udgør ca. 31/2 pct. af arbejdsstyrken.

Der stilles derfor betydelige krav om konsolidering af den offentlige økonomi for at nå det centrale mål om mindst balance på de offentlige finanser i 2015. Konsolideringen er nødvendig for at undgå en lang årrække med underskud på de offentlige finanser, der øger den offentlige gæld og dermed de offentlige rentebetalinger. Store underskud og gældsopbygning vil reducere mulighederne for at finansiere udgifter til sundhed, pleje og pension til det stigende antal ældre uden at forringe ydelsernes niveau, ligesom det kan sætte skattepolitikken under pres. Det flytter samlet set fokus mod konsolidering som et vigtigt hensyn i tilrettelæggelsen af finanspolitikken i de kommende år.

Der gøres status for de mellemfristede udfordringer i Danmarks Konvergensprogram 2009. 
Tabel 6.1. Nøgletal for dansk økonomi

\begin{tabular}{lrrrrr}
\hline & 2007 & 2008 & 2009 & 2010 & 2011 \\
\hline Realvækst, pct. & & & & & \\
Privat forbrug & 2,4 & $-0,2$ & $-4,7$ & 2,4 & 2,4 \\
Offentligt forbrug & 1,3 & 1,6 & 1,6 & 1,0 & 1,0 \\
Offentlige investeringer & $-1,1$ & $-1,1$ & 12,6 & 18,4 & $-15,0$ \\
Boliginvesteringer & 3,4 & $-14,2$ & $-17,8$ & $-6,2$ & 1,5 \\
Erhvervsinvesteringer & 3,0 & $-0,4$ & $-11,1$ & $-4,6$ & 4,2 \\
Lagerinvesteringer (pct. af BNP) & $-0,3$ & 0,3 & $-1,4$ & 0,6 & 0,1 \\
Eksport af varer og tjenester & 2,2 & 2,4 & $-8,8$ & 2,8 & 3,7 \\
Import af varer og tjenester & 2,6 & 3,3 & $-11,5$ & 3,7 & 4,1 \\
Bruttonationalprodukt (BNP) & 1,7 & $-0,9$ & $-4,3$ & 1,3 & 1,6 \\
Niveau, pct. af BNP & & & & & \\
Offentlig saldo & 4,8 & 3,4 & $-3,0$ & $-5,5$ & $-4,4$ \\
Betalingsbalancen & 1,5 & 2,2 & 2,9 & 2,4 & 2,4 \\
Niveau, 1.000 personer & & & & & \\
Ledighed (årsgennemsnit) & 78 & 52 & 101 & 155 & 155 \\
Beskæftigelse & 2.866 & 2.902 & 2.830 & 2.759 & 2.755 \\
Arbejdsstyrke & 2.944 & 2.953 & 2.931 & 2.913 & 2910 \\
Stigning, pct. & & & & & \\
Kontantpris på enfamiliehuse & 4,8 & $-3,7$ & $-14,0$ & 1,5 & 0,5 \\
Forbrugerprisindeks & 1,7 & 3,4 & 1,4 & 2,0 & 1,7 \\
Timefortjeneste i privat sektor & 4,1 & 4,6 & 3,3 & 2,7 & 2,5 \\
\hline
\end{tabular}

Kilde: Økonomisk Redegørelse, december 2009, DA og Danmarks Statistik. 